\title{
8 \\ Why did fertility fall in Tasmania during this period? Qualitative insights
}

Some scholars have used contemporary literature to

shed light on the extent of knowledge of birth control and attitudes toward reproduction and children in the past and help place the newly emerging quantitative results in their social, psychological and cultural context. (Knodel and van de Walle 1979: 219)

This chapter examines how the historical context of Australia, and of Tasmania specifically, and the historical sources of the period provide support for theories of the historical fertility decline discussed in Chapter 1: demographic transition theory, infant and child mortality, the greater accessibility of artificial methods of birth control, diffusion theory, economic theories, secularisation and changes in women's roles and status in society and in the family.

The qualitative analysis in this chapter was undertaken after the quantitative analysis was completed and its purpose is to further inform the quantitative findings and answer questions the quantitative analysis could not answer. As noted, there are three main areas of the historical fertility decline that cannot be examined using the quantitative data: how ideas and values about fertility control and knowledge of methods were diffused, what methods of contraception were used during the fertility decline and the role of women in the decline. The quantitative findings in 
relation to secularisation were also not definitive. The qualitative findings presented in this chapter address these questions and complement the quantitative findings presented in the previous chapters.

Much of the information in this chapter comes from witness statements and other published material from the 1903 Royal Commission on the Decline of the Birth-Rate and on the Mortality of Infants in New South Wales (NSW 1904a, 1904b). The royal commission was set up in 1903 to

make a diligent and full Inquiry into the Causes which have contributed to the Decline in the Birth-rate of NSW and the Effects of the Restriction of Child-bearing upon the well-being of the community. (NSW 1904a: 1)

The commissioners quickly concluded that the decline in the birth rate was due to deliberate efforts by parents to restrict their fertility. While the commissioners were vehemently opposed to fertility control and asked very leading questions of the witnesses (Hicks 1978), the published accounts provide valuable information about the historical fertility decline from people living at the time.

The Tasmanian birth rate fell about the same time as the NSW birth rate and, given the similarities between the two states, there is no doubt the qualitative evidence regarding fertility control presented to the commission for New South Wales applied also to Tasmania. The commissioners confirm this in their report, stating:

We have spoken thus far in this chapter in reference solely to the State whose population is the immediate subject of our inquiry; but what applies to NSW is obviously no less applicable to the whole of Australasia. (NSW 1904a: 172)

During this period, Tasmanian society was very similar to that of New South Wales. The states had the same culture and similar socioeconomic, education and legal systems. They were similar in terms of religion, although New South Wales was more Catholic than Tasmania. New South Wales and Tasmania were the earliest settled colonies of Australia and their settlers had similar British cultural origins. Communication between Tasmania and the other states, including New South Wales, was very good. News from the mainland states was reported daily in the Tasmanian newspapers. Ships carrying goods and people travelled several times a week between Sydney and Tasmanian ports. People moved between New South Wales and Tasmania both temporarily and permanently. Several of the 
couples in the marriage cohorts had births in Sydney or in other parts of New South Wales, with some remaining in New South Wales and others returning to Tasmania.

Some information about life in 19th and early 20th-century Tasmania comes from the diaries of two women: Amy Walker (1851-1940), who was in the 1870 marriage cohort, and Ida McAulay (1858-1949), who was a prominent feminist in late 19th and early 20th-century Hobart (McAulay 1889-90, 1890, 1897, 1898, 1899, 1900, 1903, 1904, 1905; Walker 1869, 1879, 1880, 1881, 1882, 1888, 1898; Appendix D: Stories 5 and 6 , this volume). While these women did not write about family limitation or the fall in the birth rate, their diaries provide an insight into the lives of upper-class women in Tasmania in the final two decades of the 19th century and the first decade of the 20th century and into the social and economic conditions of the time. Pregnancy was not a subject that was discussed by these women in their diaries. On 22 April 1888, Amy Walker said she 'drove to Parsonage to see Fanny who is ill', but it was not until 3 December 1888, when she 'heard that Fanny's little daughter was born last night', that it appears this illness was related to pregnancy (Fanny was Amy's sister) (Walker 1888). Similarly, Ida McAulay wrote in her diary daily during 1898 , but it is not until 8 September that we learn that her 'twins born. Ida: $5 \mathrm{lb} 3$ oz. Mollie 5 lbs 10 ozs' (McAulay 1898).

Other historical sources used in this chapter include articles or items from late 19th and early 20th-century newspapers of Tasmania and other colonies, and stories about people in the Tasmanian marriage cohorts.

\section{Demographic transition theory}

The social and economic conditions of Tasmania at the time of the historical fertility decline provide some support for demographic transition theory. Tasmania became more urbanised in the late 19th century and there was marked social and economic development.

The colony became more industrialised in the final two decades of the 19th century with the growth of the mining industry, which overtook agriculture in terms of its importance to Tasmania's economy. The proportion of the population employed in agriculture fell steadily from 1871 . By the beginning of the 1880 s, the income from mining exports was greater than that from wool and, by the end of the century, more than 
half the value of Tasmanian exports was derived from minerals. The colony also became more urbanised; by 1901, half the population was living in an urban setting - that is, in Hobart, Launceston and their suburbs, or in towns with populations of 500 or more that were close to one another and to the larger cities of Hobart and Launceston.

The 1870s, 1880s and 1890s were a time of 'modernisation' and economic and social development in Tasmania. The railways came to Tasmania from the early 1870s and spread throughout the colony in the 1880s and 1890s; the electric telegraph link between Tasmania and Europe was established in 1872 and Hobart and Launceston were connected with electric lighting in the 1890s. Agriculture became more mechanised in the 1890s and early 1900s. The Education Act of 1868 introduced compulsory education for children aged seven to 12 years and the 1873 Public Schools Amendment Act extended this to 14 years. The proportion of the population who could both read and write improved markedly between 1861 and 1901 . There was rapid growth in 'modern' occupations, particularly whitecollar occupations such as 'accountant', 'bank clerk', 'insurance agent', 'schoolteacher' and 'railway porter'. Some of the new occupations were within the growing transport and communications sectors.

Amy Walker's diaries mention many of the innovations of the time, as do Ida McAulay's diaries, which were written at a later date (Walker 1869, 1879, 1880, 1881, 1882, 1888, 1898; McAulay 1889-90, 1890, 1897, 1898, 1899, 1900, 1903, 1904, 1905).

Both women's diary entries illustrate changes in methods of transportation that occurred in the final two decades of the 19th century. To get from their estate, 'Clarendon', near Gretna, to Hobart, in 1879, the Walkers had to drive in a horse and carriage to Bridgewater to catch the train to Hobart; in 1888, they drove to New Norfolk (closer to Gretna) to take the train to Hobart; while in 1898, 'Captain H. came to dinner also Edgar and Marie David, riding their bicycles from the train' (Walker 1879, 1888, 1898). Both Amy and Ida took the train from Hobart to Launceston on several occasions (Walker 1879, 1880, 1882, 1888; McAulay 1899). Ida McAulay also regularly took the electric tram from Hobart to Sandy Bay (McAulay 1904). Ida bought a bicycle in May 1897 and learned to ride it, going on bicycling expeditions in later years (McAulay 1897, 1904). 
Although Amy Walker and Ida McAulay wrote countless letters to friends and family, telegrams played an important part in their lives. On 15 January 1879, for instance, Amy Walker wrote 'received a telegram from Mama' (who lived in Hobart) and, on 18 January 1879, she 'sent a telegram to Mama asking for extended leave for Arthur' (her younger brother, who was staying with her) (Walker 1879). Ida McAulay often sent telegrams from her home in Bellerive to people living across the Derwent River in Hobart (McAulay 1897). Few people had telephones at this time, but in April 1904, Ida wrote that a friend 'received a telephone call' (McAulay 1904).

Amy Walker's diary entries mention some of the industrial and agricultural innovations of the time. In March 1882, when visiting Launceston, 'John, Leslie and I went to see the Bischoff Smelting works in the evening after dinner' (Walker 1882). On 17 January 1888, she wrote that 'John, Violet and Maudie went over to French's Forest to see a reaping machine at work on the plains', and on 9 May of that year, 'Our threshing machine arrived in the afternoon' (Walker 1888).

Ida McAulay's diaries talk about the movement of people out of Hobart to the mining towns in the far west of the colony in the final decade of the 19th century. In August 1899, she wrote:

I went to town to try to get a girl for a fortnight. Impossible to hear of one. Everyone wanting servants and no one can get them. They all go to the West Coast. (McAulay 1899)

The 1880 s and 1890 s were a time of new ideas for Tasmania and improvements in education opened up people's minds to these ideas; 'reform and progressive legislation characterized the period' (Robson and Roe 1997: 50). For example, the Women's and Children's Employment (Factories) Act of 1884 specified that women could not be employed for more than 10 hours a day and children for more than eight (Sprod 1984). The Public Health Act came into effect throughout the colony in 1885, leading to the setting up of local health boards, the closure of cesspits and the eradication of typhoid within a short period (Robson and Roe 1997). The 1885 Education Act tried to rectify some of the problems of poor school attendance, albeit with limited success. There was also pressure to reform laws related to women, including changing the age at which women could marry from 12 to 16 years (Robson and Roe 1997). In 1896, a bill for female suffrage was passed in the House of Assembly with a large majority but was rejected in the Legislative Assembly (Reynolds 2012). However, women were finally given the right to vote six years later. 
As members of the upper class, Amy Walker and Ida McAulay were highly educated women and were interested in life outside the home. Both women went to parliament in Hobart to listen to debates about several matters (McAulay 1897; Walker 1898). Ida McAulay, in particular, was very interested in and receptive to new ideas. She belonged to a reading group and a discussion group. In January 1897, the latter group discussed 'the nationalization of land'; in July 1897, there was a 'discussion of Australia separating from England and becoming a nation itself'; and in October 1899 , she took part in a debate on 'woman's suffrage', speaking in favour of the proposal (McAulay 1897, 1899). Before she was married, Ida read Darwin's On the Origin of Species and The Descent of Man (McAulay 1889).

\section{Infant and child mortality}

One element of demographic theory is not supported by the situation in Tasmania—that is, a decline in infant mortality is a necessary condition for fertility to decline. There is no evidence from sources of the period to support theories about the relationship between infant mortality and fertility control. Between 1860 and 1899, the infant mortality rate for Tasmania was relatively flat, despite large annual fluctuations (Kippen 2002c). Infant mortality began to decline in Australia only at the turn of the century-well after fertility had started to decline (McDonald et al. 1987). In Tasmania, infant mortality rates fell from around 100 infant deaths per 1,000 live births in the 1890s to around 55 infant deaths per 1,000 live births in the 1920 s.

The 1903 NSW Royal Commission on the Decline in the Birth-Rate investigated the causes of the fall in the birth rate and the high rates of infant mortality but concluded the two were not linked:

The decrease in infant mortality may be a consequence of the decline in the birth rate, but the converse is not true ... there may be a high infant death-rate together with a low birth-rate. (NSW 1904a: 13)

I have not found any historical sources that discuss any link between the fall in child mortality and the fertility decline in Australia. In Tasmania, the mortality of children aged one to 14 years started to decline several years before the decline in infant mortality. 'Male and female child mortality fell by half from 1860-64 to 1895-99' (Kippen 2002c: 239). For both boys and girls, the decline was due mainly to a fall in deaths from 
epidemic diseases followed by a fall in deaths from accidents. The 'clear downward trend' in the child mortality rate was interrupted in the second half of the 1870s by two epidemics - one of measles and one of scarlet fever (Kippen 2002c: 66). John and Sarah Chick, a couple in the 1870 marriage cohort, lost their four children, aged one to six years, to scarlet fever in the five days between 30 September 1876 and 4 October 1876.

It is probable that most women in 19th-century Tasmania knew someone who had a child die in infancy. In almost all of Amy Walker's diaries, she mentions the death of a baby of a friend or family member. On 30 May 1880, Amy 'wrote to Mrs Milne who has just lost her little baby', while on 23 April 1888, she wrote she had 'heard the sad news of Arthur's little daughter's death this morning at 5 o'clock' and, on 27 July 1898, 'Miss Collier came to see me telling me of the death of Mrs Widdicourse's baby' (Walker 1880, 1888, 1898). Amy's diaries written during her married life do not mention deaths of small children, but her diary written the year before she was married notes, on 29 July 1869: 'Yesterday, poor little Archie was run over in the street and killed' (Walker 1869).

\section{Methods of contraception}

Historical sources indicate that, in Australia, the availability and use of artificial methods of contraception increased markedly in the late 19th and early 20th centuries - that is, during the period in which marital fertility started to decline. The methods that were probably used prior to the decline, such as 'withdrawal' and abortion, also became more common.

Although they could not be specific about timing, many witnesses to the 1903 NSW Royal Commission testified that the purchase and use of artificial methods of contraception had greatly increased in the preceding 20 years, as had the practices of 'withdrawal' and abortion. Other evidence shows that, in the late 19th and early 20th centuries, wholesale drug companies imported into New South Wales French letters (condoms), the India rubber Pessaire Preventif, Rendell's soluble pessaries and safety sponges (NSW 1904b: 13, 15). Some wholesale druggists and pharmacists also made their own soluble pessaries (NSW 1904b: 15, 20). Enemas, douches and syringes sold by pharmacists were also used for contraceptive purposes. 
Witnesses to the royal commission agreed that almost all pharmacists in Sydney stocked contraceptive devices, but this was not the case in the country. ${ }^{1}$ Dr Cosby Morton, a general practitioner who had practised in several country areas, said: 'Many country chemists sell them; I would not say all'2 (NSW 1904b: 27). Preventives were also sold by hawkers, including women, in both the city and the country (NSW 1904b: 18, 24, 27). Some Sydney drug companies and pharmacists sold preventives to country people by mail (NSW 1904b: 21, 44).

Testimony from pharmacists to the royal commission indicates the demand for artificial contraceptives was high, despite the reluctance on the part of a few pharmacists to sell them. Thomas Loney, a pharmacist in William Street, Sydney, said:

For a great many years, I have absolutely refused to sell those articles at all, but during the last year or two the demand for them has become so imperative that I have been obliged to keep them. (NSW 1904b: 35)

William Park, a pharmacist in Pitt Street, Sydney, was one of the very few pharmacists who refused to stock preventives:

I don't sell preventives. I don't believe in them. I am asked for these articles every day. The day before yesterday I had four people within an hour ask for these quinine pessaries. (NSW 1904b: 40)

The demand for female preventives was so high that, in the late 1890s, Washington Soul, the largest pharmacy in Sydney, established a 'nurse' in a kiosk in its city store solely to sell articles to women. 'Nurse B' told the commissioners:

My particular duties are to attend to ladies with articles that are kept in my room—such as enemas, douches, elastic goods, belts, accouchement sheets, sanitary towels, breast pumps, trusses and such articles as those ... I have sold women rubber pessaries or medicated pessaries and safety sponges. (NSW 1904b: 57)

It is not possible to obtain information on the total number of artificial contraceptives sold in New South Wales during this period. However, data provided to the commission from the Customs Department showed the

1 'Country' in this Australian context refers to all areas outside the major cities. The 'country' was also referred to as the 'bush'.

2 A 'chemist' was a pharmacist. 
number of preventives imported into the state in three sample months in 1903 and 1904 was not large. The October 1903 return shows the highest number of imports: 100 gross French letters (14,400), 212 dozen boxes of Rendell's pessaries, 22 dozen pessaries, 20 gross Pessaire Preventif and 10 gross Bandruche Skins (NSW 1904b: 311).

Most artificial contraceptives were relatively expensive in relation to the average wages of working-class and even some middle-class men. The wages of working men ranged from 30 s to $£ 2$ 8s per week, while lower-white-collar workers generally earned from $£ 2$ to $£ 3$ a week (NSW 1904b: 29, 45, 106, 264-5). India rubber pessaries cost from 8s 6d to $£ 2$ s each, while soluble pessaries cost from 3 s a dozen and French letters from 6s a dozen (NSW 1904b: 363-5, 383, 385). Many witnesses told the royal commission it was common for women to use less expensive methods of prevention or to make their own preventives.

Several witnesses testified that the use of syringes, douches and enemas was common practice. William Sharland, representative of the Parke Davis Drug Company, told the commission: 'I think that the latter are the growing class of preventives - that is the douching of the canal with enemas and douches with antiseptic solutions' (NSW 1904b: 24). J.A. Masterton, a pharmacist in Market Street, Sydney, said: 'Others will not go to the expense of anything; they simply use their syringe with an astringent lotion straight away, and that answers the purpose just the same' (NSW 1904b: 30). Dr Robert Scot-Skirving, a physician and surgeon at two major Sydney hospitals, reported that in 'the bush, and among the lower classes generally, the preventive as a rule, is syringing immediately after connection either with hot or cold water' (NSW 1904b: 101).

Many witnesses told the commissioners that women made their own soluble pessaries. J.A. Masterton said:

Referring to these soluble pessaries, they are made of cocoa butter, which is the vehicle to carry the quinine that is in them and is the sterilising agent. Now a great number of people buy cocoa butter by itself, and they buy quinine by itself. (NSW 1904b: 30)

George Stevens, a pharmacist in a working-class inner-city part of Sydney, reported: 'They come and buy $3 \mathrm{~d}$. worth of cocoa butter and some quinine and they mix it up themselves' (NSW 1904b: 43). Dr John Harris, who had been a general practitioner in Newcastle, NSW, for 30 years, said: 
There are a larger percentage of women now who know how to prepare their own pessaries. They use quinine and sulphate of zinc and make them up with cocoa butter themselves. It is common for women to make their own pessaries and introduce them into the vagina and leave them there. (NSW 1904b: 125)

Several witnesses testified that it was common for women to use sponges for preventive purposes, with many women making their own contraceptive sponges. Sir James Graham, who was an honorary surgeon at two major Sydney hospitals, said: 'One frequently finds, in the ordinary outdoor clinic ${ }^{3}$ of a woman's hospital, evidence of sponges and the like' (NSW 1904b: 114). J.A. Masterton reported:

There are sponges used-small sponges. Now these sponges are designed for the same thing. Well, a great number of people will not go [to] the trouble of buying a sponge. They buy the ordinary toilet sponge and cut it into pieces and they tie a tape to them, and they use them themselves. (NSW 1904b: 30)

Several doctors gave evidence to the royal commission that 'withdrawal' was used to prevent conception. Dr Scot-Skirving said: 'I think that withdrawal is practised to a considerable extent' (NSW 1904b: 101). Dr William McKay, medical officer at a suburban Sydney hospital, told the commissioners: "The main method is the withdrawal of the male organ before the act is completed' (NSW 1904b: 105). Dr Ralph Worrall, senior visiting surgeon to the Sydney Women's Hospital, also thought withdrawal was very common (NSW 1904b: 88).

Some scholars have used this testimony to conclude that withdrawal was the most common method used to prevent conception during the Australian historical fertility decline (Pringle 1973; Quiggin 1988; Bongiorno 2012), but evidence from other witnesses to the NSW royal commission does not support this view. Additionally, when McKay's statement is examined in more detail, it appears he is primarily talking about the use of withdrawal by the middle classes:

Prevention is more common in the middle classes. I mean men earning say $£ 2$ a week in offices ... it is not so common among the working classes, because the man will not submit to it. The woman might be quite willing, but the man will not submit. (NSW 1904b: 105)

3 An 'outdoor clinic' was an outpatient clinic at a public hospital for poor and working-class women. 
Overall, witnesses to the royal commission indicated that femalecontrolled preventives - that is, soluble pessaries, syringes, douches, enemas and sponges-were commonly used by women of all classes to prevent pregnancy. Soluble pessaries were more popular than French letters, which were used to prevent disease as well as conception (NSW 1904b: 16, 29). Most pharmacists reported the sale of pessaries had overtaken that of French letters in recent years. George Stevens said: 'There is not much sale for the French letters since the pessaries have come into vogue' (NSW 1904b: 43).

Abortion was another method used to limit family size in Australia in the late 19th and early 20th centuries, despite being a criminal offence. Until Federation in 1901, the Australian colonies were subject to the UK Offences Against the Person Act of 1861, which made abortion illegal under any circumstances. After Federation, abortion remained a criminal offence under different state legislation.

Most witnesses to the NSW royal commission attributed the decline in the birth rate to both prevention and abortion, with many saying prevention was more commonly used by the middle class to limit family size and abortion more commonly used by the working class (NSW 1904b). Almost all the witnesses-doctors, pharmacists, clergymen, police officers and others-reported that induced abortion was a common practice among both married and unmarried women. Most pharmacists reported a demand for pills that women used to try to procure abortions, such as 'Towle's Pennyroyal and Steel Pills' and 'Dr Boxwell's Silent Pills' (NSW 1904b: 357). Abortifacient pills were sold throughout Sydney and in all country areas (NSW 1904b: 28). They were also available by mail through advertisements in the newspapers (NSW 1904b: 30).

Witnesses to the royal commission reported that there were many abortionists operating in Sydney and some in country areas. These were mainly qualified and unqualified nurses and a very small number of doctors in Sydney, and unqualified midwives in the country areas. James Sawtell, senior sergeant of police in Sydney, thought the procuring of abortions was very prevalent in Sydney: 'I know of 36-38 reputed abortionists, mostly women in my own district. I also know of five legally qualified medical men' (NSW 1904b: 52). Dr Joseph Foreman, senior gynaecological surgeon to the Prince Alfred Hospital, said: 
The prevalence of abortion is almost incredible. The cases that are always coming in and taking up the beds in the hospitals are quite sufficient to show to what extent it prevails. (NSW 1904b: 229)

Most of the witnesses agreed that women of all classes used abortion to limit their families but thought the practice was more common among the working class. Arthur Glover, a general practitioner in a poor working-class district of Sydney, told the commissioners of the desperation of some of his married women patients:

They are aware that abortion is a criminal act ... and several of them, if you tell them how dangerous it is, say they will die before they will have another child. (NSW 1904b: 110)

Many witnesses reported that it was common for country women to come to Sydney to procure an abortion.

McCalman's (1988) study of female patients at a large public hospital in Melbourne shows that abortion was common in Melbourne in the late 19th century. In Adelaide also, several cases of abortion by a well-known abortionist, Madame Harper, were reported in the local newspapers in the late 19th and early 20th centuries (Anderson and Mackinnon 2015).

No data are available on the extent of induced abortion during the fertility decline. Some NSW hospitals provided data to the royal commission on cases of 'abortion or miscarriage' treated in the preceding five years, but it is impossible to separate out the two (NSW 1904b: 297-8, 312-13). In Tasmania, 27 women were recorded as dying from 'abortion' or 'miscarriage' between 1860 and 1899, almost all of them married, with 17 of all deaths occurring in the 1890s (Tasdeaths). Louisa Collings, who was in the 1890 marriage cohort, died from an abortion in May 1901 at the age of 31 years - some 18 months after she had her fifth child. The Tasmanian newspapers in the late 19th and early 20th centuries contain several accounts of women dying in Tasmania from illegal abortions performed by midwives, doctors and other persons (Daily Telegraph, [Launceston], 18 January 1890, 5 June 1894; The Mercury, [Hobart], 12 March 1879, 26 August 1910; The Examiner, [Launceston], 4 November 1891; The North Western Advocate and the Emu Bay Times, [Devonport], 19 August 1901).

Almost all the clergymen testifying to the royal commission thought sexual abstinence was the only method people should use to limit their families if this became absolutely necessary-for instance, if the wife's 
life became endangered by pregnancy (NSW 1904b: 202-26, 275-7). However, none of the evidence to the commission mentioned the use of abstinence as a preventive measure.

\section{Diffusion theory}

There is considerable evidence to support diffusion theory as one of the explanations for the historical fertility decline in Australia. Ideas and values about fertility control as well as the knowledge of the methods used to limit fertility clearly spread through Australian society in the late 19 th and early 20 th centuries.

As noted, Tasmania was not an isolated place in the second half of the 19th century. Communication between Tasmania and the mainland colonies and between Tasmania and English-speaking countries and Western Europe was very good.

Amy Walker's diaries indicate that the upper classes in Tasmania were in constant communication with people living outside Tasmania and they regularly travelled to other colonies and, on some occasions, to other parts of the world. The Walkers often had visitors from Melbourne, Sydney, New Zealand, England and other countries and had friends and family who travelled to these places. Several of Amy Walker's friends, neighbours and family went to stay in England and her brother Arthur went to study medicine in Edinburgh (Walker 1879, 1880). For example, on 12 December 1879, Amy 'wrote to Maria Parsons who has just returned from England with her husband and children'; on 25 May 1881, she went to a reception at Government House and met some of the officers from the Japanese warship Gingo; and, on 15 April 1882, she received 'letters from mother and Lilian posted at Honolulu' (Walker 1879, 1881, 1882). Ida McAulay went to Europe in 1889-90 before she was married, visiting cities such as Naples, Paris, Brussels and London (McAulay 1889-90). In 1897, Ida wrote about friends who were travelling to Sydney, Melbourne, the United States, England and South Africa (McAulay 1897).

Lower-class people were also in contact with others outside Australia. On 18 May 1881, Amy Walker wrote that her cook, 'Minnie heard of her sister's death in New Zealand and decided to go there'; and on 13 February 1882 , one of the servants, 'Clara went to town for a holiday and to see 
about some money sent her from England' (Walker 1881, 1882). Several families in the four marriage cohorts of all classes left Tasmania for other colonies or New Zealand and later returned to Tasmania.

Communication between Tasmania and the rest of the world improved dramatically in the 1870 s with the establishment of the electric telegraph cable between Tasmania and London. English news could now reach Tasmania in several hours rather than months (Cox 2012) and Tasmanian newspapers could publish news and articles shortly after they appeared in the English newspapers. Some of these articles concerned the trials of people for distributing information about birth control.

The 1903 NSW royal commissioners considered the spread of values regarding fertility limitation and information about fertility control methods was one of the main reasons for the fall in the birth rate from the mid-1880s (NSW 1904a). They reported that, in the final quarter of the 19th century, values about fertility control had spread throughout the 'civilised world' and there was a 'general diffusion of the knowledge of methods by which restriction might be accomplished which was previously wanting' (NSW 1904a: 17).

Some witnesses to the commission reported that the use of prevention first started with the upper classes. Dr Stanley McCulloch, honorary surgeon to the Sydney Women's Hospital, said family limitation was 'first observed by the well to do (I mean the comfortable class). I think it is spreading to the working classes' (NSW 1904b: 71). Most witnesses to the commission agreed that, by 1903 , measures to limit the size of their families-either prevention or abortion - were used by people in all classes in New South Wales and by those in the country as well as the towns. However, they thought people in the country were less likely to use these measures. Dr Worrall reported:

I have observed this tendency [to limit their families] ... in every class in the community, but the higher classes resort to prevention of conception more frequently and the lower classes to the induction of abortion. I have noticed it with my patients from the country. They are just as familiar with the methods adopted as the people in the town, but do not practise it as frequently as town folk. (NSW 1904b: 89)

Birth control literature from overseas became available in Australia from the late 1870s. Books and pamphlets about birth control such as Knowlton's Fruits of Philosophy (1878), Annie Besant's The Law of 
Population (1887) and Allbutt's The Wife's Handbook (1888) were available in Sydney and Melbourne bookshops and lectures on 'family limitation' were given in Melbourne and Sydney (NSW 1904b; Quiggin 1988; Bongiorno 2012). Brettena Smyth, a widow who ran her own pharmacy, gave frequent women-only lectures in the North Melbourne Town Hall and other locations around Victoria that were attended by hundreds of women at a time (McDonald and Moyle 2018). These lectures were freely advertised and reported on in the leading Melbourne newspapers. Smyth's book The Limitation of Offspring (1893), which covered aspects of reproductive health, including the use of contraceptive devices, was based on these lectures.

Many witnesses to the NSW royal commission mentioned Fruits of Philosophy and several of them had read it. The commission also heard evidence that pamphlets advertising preventives were in circulation in Sydney. Subinspector of police James Mitchell said of a handbill advertising the French Pessaire Preventif:

Many complaints have been received from citizens that handbills of this character have been left at their houses with their female relatives. They are left door to door and we have had complaints of their being sent to people by post or other means. (NSW 1903b: 51)

It is not clear whether these books and pamphlets were available to the same extent in the country as in the city. The Reverend John Howell-Price, a Church of England clergyman from Richmond, a country area outside Sydney, said 'Bradlaugh's books and Mrs Besant's books and other books which are freely obtainable in Sydney are largely read in country places', but he thought leaflets and pamphlets were not generally distributed in country areas (NSW 1904b: 214).

Amy Walker and Ida McAulay both read for pleasure and for selfedification and they exchanged books of interest with other upper-class women. Neither of them mentioned books about fertility limitation, but on 21 January 1898, Ida wrote in her diary: 'Evening went round to the Victoria Club to take Miss Martin Annie Besant's autobiography to read' (McAulay 1898).

Advertisements in newspapers and journals were a major source of information about fertility control in late 19th and early 20th-century Australia (Quiggin 1988; Bongiorno 2012). The 1903 NSW Royal 
Commission found newspapers in metropolitan, suburban and country New South Wales regularly contained advertisements for books and pamphlets providing information about methods of prevention and for the sale of preventives and abortifacients (NSW 1904b: 30, 39, 50, 87, 95, 271-2). Dr Edward Thring, a gynaecologist at a large Sydney hospital, thought:

The general public are familiarised very much more now than they used to be with the methods by which prevention of pregnancy can be made to take place ... and I think that one reason for that is the free advertising - I mean to say, the extensive advertising [of] the various preventive methods which has taken place during the last, say, 20 years- the knowledge that there are various mechanical means which can be obtained by purchase for the prevention of impregnation. (NSW 1904b: 93)

Tasmanian newspapers such as The Examiner, The Clipper (Hobart) and The Mercury regularly included these types of advertisements:

Women's Salvation-The wife's welfare within her control. Treatise posted free, sealed. Write to Professor Herman, French Specialist, 41 Collins Place, Melbourne. This treatise will teach you more about prevention in ten minutes than all the years you've lived. (The Examiner, [Launceston], 20 September 1894; The Clipper, [Hobart], 20 April 1895)

A Blessing to Womankind, Pessaire Preventif: every mother delicate or otherwise should write for particulars to Dr A.K. Desjardien, Post Office Hobart. (The Examiner, [Launceston], 27 September 1885)

Gents' latest American preventives, simple effective, last for years. 2s $6 \mathrm{~d}$ posted. Write W.H. GARFIELD, Collins St, Melbourne. (The Clipper, [Hobart], 20 July 1895)

Gents' best made French preventives. 6s per dozen, posted. Write R.R.HERMANN, Collins Place, Melbourne. (The Clipper, [Hobart], 20 July 1895) 
Alfaline Quinine Pessaries-A guaranteed harmless Preventative. Posted (from Sydney) ... 5/6. (The Clipper, [Hobart], 19 August 1902)

Towle's Pennyroyal and Steele Pills for Females. Quickly correct all irregularities and relieve the distressing symptoms so prevalent with this sex. Boxes $1 \mathrm{~s} 1 / 2 \mathrm{~d}$ and $2 \mathrm{~s} 9 \mathrm{~d}$ of all chemists and patent medicine vendors. (The Mercury, [Hobart], 17 March 1888)

Oriental Female Pills. Triple Power. Restore regularity without fail. Any cause. Sure and Safe. Box posted 5s and 6d. Write, M. Garfield, Agent, West Collins St, Melbourne. (The Clipper, [Hobart], 20 April 1895)

Police officers appearing before the NSW royal commission reported that advertisements from well-known abortionists regularly appeared in the newspapers (NSW 1904b: 51-2, 183). However, these advertisements were written in a general way to obscure their true purpose: 'Nurse P. attends ladies during accouchement. Registered lying in home, 550 Cleveland St. Moore Park' (Sydney Morning Herald, 24 October 1902, cited in NSW 1904b: 186).

Similar advertisements for 'lying-in homes' appeared in the Tasmanian newspapers in the late 19th and early 20th centuries, and it is likely some of these establishments were also used to procure abortions.

News about the trials of prominent people for obscenity-because they were publishing and/or distributing information about methods of birth control—spread throughout Australia from the late 1870s. The BradlaughBesant trial, which Caldwell (1999) argues was a catalyst for the adoption of birth control, was reported in all the Australian newspapers, including Hobart's The Mercury and Launceston's The Examiner. The Mercury reported on 13 August 1877:

The trial of Mr Bradlaugh and Mrs Besant, before the Lord Chief Justice and a special jury, lasted five days and in their verdict the jury found the defendants guilty of publishing a work calculated to debase public morals, but exonerated them from all corrupt motives. A new trial will be applied for, and $\mathrm{Mr}$ Bradlaugh intends to carry the case to the House of Lords. 
The book Fruits of Philosophy was again referred to in an article in The Mercury on 25 August 1877 reporting proceedings in the British House of Commons, quoted verbatim from the London Times. Another article in The Mercury, of 26 February 1878, compared an obscene pamphlet published in Melbourne to

that notorious work 'Fruits of Philosophy' published by Mr Bradlaugh and Mrs Besant, and for which they were deservedly convicted and sentenced to be fined and confined, though the conviction has since been upset in the Supreme Court.

Collins booksellers was tried for obscenity in Sydney in 1888 for selling Annie Besant's book The Law of Population, but Judge Windeyer ruled the book was not obscene and Collins had a right to sell it. This judgement was reported in newspapers in all the Australian colonies, including Tasmania:

In the Banoo Court this morning, before the Chief Justice, Mr Justice Windeyer and Mr Justice Stephen judgment was delivered in the appeal of William Whitehouse Collins against his conviction by Mr. Addison, P.M. for offering for sale a certain indecent and obscene book entitled 'The Law of Population'. The Chief Justice reviewed the arguments in connection with the work entitled 'Fruits of Philosophy' ... Justice Windeyer delivered a lengthy opinion and said that it had been admitted that an abstract discussion on the law of population was a fitting one for the philosopher and the student of sociology; His Honor gave it as his opinion that the prohibition should go, as the book did not come under the designation of obscene. Justice Stephen concurred that the prohibition should be ordered to go and the conviction was quashed. (The Mercury, [Hobart], 19 December 1888)

The NSW royal commissioners considered that Justice Windeyer's judgement legitimised the practice of fertility control and blamed it for the 'sudden fall in the birth rate' that occurred in New South Wales in 1889 (NSW 1904a: 18). This was disputed by a witness to the commission, Sydney Maxted, who was chief boarding officer for the state Children's Relief Department and also a 'newspaper man'. He thought the Windeyer judgement

at the time created a sensation, but I think it was less than a 9-days wonder and if you were to ask almost anybody in the street if those remarks were made I do not think you would get an affirmative answer, except from someone who takes a special interest in the question. (NSW 1904b: 96) 
Maxted argued instead that midwives read these books and pamphlets and then provided the information to their patients:

The midwives tell them how to do it. Years ago, they did not know, but of course by the dissemination of this literature that you have just spoken about, the knowledge gets into the minds of the midwives; they study it, and then they tell the people. A woman will attend another woman, and she will say 'Now, I will tell you how to stop having any more children' and she does. (NSW 1904b: 97)

Many witnesses told the commissioners that information about prevention was spread by word of mouth among women. Women discussed ideas and values about prevention with other women and gave them information on how to limit their births. The Reverend HowellPrice said:

One of the most intelligent ladies that we have in the district is a very keen advocate of prevention, alleging various reasons why prevention should be practiced ... This information is communicated to the unmarried and to married persons. (NSW 1904b: 214)

\section{Pharmacist George Stephens reported:}

There is a peculiar thing about women; they will tell one another and they simply come along and ask for them [quinine pessaries] ... they spread the information amongst other women ... Knowledge travels from one woman to another in the country. (NSW 1904b: 44)

One of the few female witnesses, Witness E, a 47-year-old woman who had borne 16 children, said:

Ever since my early married life, some of my friends have spoken to me about prevention. They have advocated it ... People seem to be well acquainted with the methods of preventing impregnation. I have been spoken to myself by different people about all sorts of ways. They discuss the different methods among themselves openly among women of every class. (NSW 1904b: 189) 
Dr Foreman added:

They acquire the knowledge from the propagandists amongst themselves ... there is one woman ... who goes about telling other women; at all the tea meetings, at all the drawing rooms, it is the subject of conversation. There is not a woman scarcely who comes to me who does not know what to do to prevent conception. (NSW 1904b: 228)

The Reverend Nicholas Hennessy, a Congregationalist clergyman, thought:

Women themselves have helped to spread the evil ... they are very free (those of them who have either one child or very small families) to tell a woman who has many children the means by which she can prevent the birth of more. (NSW 1904b: 207)

None of the doctors who gave evidence to the commission reported giving information about preventive methods to their patients. However, some doctors were involved in giving their patients access to preventives. Alfred Silly, managing director of the Australian Drug Company, sold preventives to doctors (NSW 1904b: 20), while Lewy Pattinson, a Sydney pharmacist, told the commission that women fairly frequently brought in doctors' prescriptions for preventives: 'I got one this morning from a doctor of good repute-for a box of Rendell's soluble pessaries. He is a leading doctor in Sydney' (NSW 1904b: 37). Nurse B from Washington H. Soul pharmacy in the city reported: 'Medical men of the highest standing have advised women to come to me' (NSW 1904b: 58).

The question of family limitation had become a legitimate topic for public discussion in Australia by the beginning of the 20th century. George Mullins, a Sydney general practitioner, told the commissioners:

One hears so much about the limiting of families, and the various ailments to which men and women are liable which one did not hear some years ago; these are subjects of ordinary conversation at the present day which were not 10 or 12 years ago. (NSW 1904b: 66)

An analysis by Hicks (1978) of Australian newspapers of the period shows that discussion about the birth rate and family limitation was much more open in the early 1900 s than in the 1870 s or 1880 s. In the early years of the 20th century, there were numerous editorials, articles and letters in the main Sydney, Melbourne and Adelaide newspapers about the fall in the birth rate and the reasons for the decline. During the same period, 
the Hobart and Launceston and some country newspapers contained articles and letters about the fall in the birth rate and family limitation in Australia and overseas. The Tasmanian newspapers reported on the NSW royal commission's findings in some detail (for example, Daily Telegraph, [Launceston], 7 March 1904; The Mercury, [Hobart], 7 June 1904). Two country newspapers published articles on a deputation to the Premier of Victoria on 'race suicide', reporting on 'preventive articles' sold by most Victorian pharmacists and 'a wicked and growing traffic in appliances for bringing about abortion' (Zeehan and Dundas Herald, 25 July 1909; The North Western Advocate and the Emu Bay Times, [Devonport], 27 September 1909).

\section{Economic theories}

There is considerable evidence to support economic theories of why fertility declined during this period. While it appears some people were restricting their fertility before the economic depression of the early 1890 s, the increase in unemployment and the fall in wages that occurred in Tasmania provided great incentives for couples to adopt fertility control measures. Although conditions had improved by the end of the 19th century, for some groups of workers, wages were not as high as they had been in the 1880s.

Letters published by Sydney, Melbourne and Adelaide newspapers in the first decade of the 20th century show that economic reasons were important in the fertility decline. At least half of those writing to these newspapers about the declining birth rate gave economic factors as the main reason for limiting family size, complaining of unemployment, a lack of regular employment and increases in the cost of living (Hicks 1978).

Australia offered many opportunities for social mobility and this may have encouraged the practice of fertility control. Australian society was less rigid than English society and many people were able to realise their social and economic aspirations-sometimes within one generation (Breward 1988):

While many of Australia's early migrants were from humble origins, they included many with great natural ability, who were able to use their gifts in the more open-textured Australian communities to achieve a degree of wealth, position and responsibility which would never have been possible in Britain. (Breward 1988: 24) 
There are many examples of social mobility in the four marriage cohorts. For example, Samuel Sutton (1860 cohort), who was a baker during the 1860s, became a Member of the Tasmanian Parliament in 1886 (Appendix D: Story 7); David Dally (1870 cohort) was a lime dealer in the early 1870s, but became rich when he and his brothers discovered the famous Tasmanian (gold) Reef in 1877 (Appendix D: Story 8); and Joseph Lyons, the son of Michael Lyons (1870 cohort), a farmer and a butcher, became Premier of Tasmania in 1923 and Prime Minister of Australia in 1932 (Appendix D: Story 9).

In New South Wales in the early 1900s, many witnesses to the royal commission gave economics as one of the main reasons couples wanted to limit their families (NSW 1904b). Several witnesses regarded this as 'selfishness' on the part of these couples.

A continual theme of witness statements to the commission was that couples wanted to limit their families because of the costs of having children - that is, the cost of another child outweighed the benefits of having that child. Implicit in these statements was the view that people in all classes wanted a better future for their children - that is, they had social and material aspirations for their children.

Edmund Fuss, a pharmacist in a working-class area of Sydney, said of the middle and working classes:

People are trying to acquire knowledge, in my opinion to get means to prevent having large families, for the simple reason that they have not means to support their children or to educate them. (NSW 1904b: 29)

Dr Worrall reported: 'I ask them over and over again and they say they cannot afford to rear and educate their children' (NSW 1904b: 89). Dr Scot-Skirving added:

A good many of them say 'Well I can afford to educate and take care of two or three children, but I cannot give six a good education': so they say 'Well, I will not have any more than three'. (NSW 1904b: 97)

Many witnesses thought couples in all classes used prevention because they wanted to maintain their standard of living or aspired to a higher standard of living for themselves and/or their children. Dr Mullins 
reported that people told him 'it is too expensive ... in many cases they can afford it, but they want the money for other purposes' (NSW 1904b: 66). Dr McKay said:

In the majority of cases the reason given is that they have not got the money to support them ... If these people have only $£ 2$ a week and have good clothes and live in a better class of house, they cannot support a large family. (NSW 1904b: 106)

John West, a master plumber and secretary of the Trades Hall Council, exemplified the situation of a working man with aspirations for his children:
A working man with 4 or 5 children on $£ 2$ per week would exist and manage to get through it very well, but of course he would have to debar himself from luxuries. When I was earning less money I managed to save a little and when I got more my family wanted more. When I was on wages I could not get my daughters taught music. As soon as I was able to get in a bigger way, I let my girls learn the piano. (NSW 1904b: 200)

The aspiration to own their own home became part of the desire for a higher standard of living for working-class and middle-class families in Australia in the final two decades of the 19th century. 'The level of owner-occupation ... was unquestionably very high by world standards' (Davison 2004: 219). Between one-third and one-half of homes in Melbourne, Sydney and Adelaide were owned or were being bought by their residents in the late 19th and early 20th centuries. Although we do not have Tasmanian data on home ownership in the late 19th century, the 1911 Australian census shows that 44.7 per cent of private dwellings in Tasmania were occupied by people who owned or were purchasing their home (Commonwealth of Australia 1914a: 419).

Several witnesses to the royal commission labelled the desire for a better standard of living as 'pleasure seeking'. Edmund Fuss thought wealthy people purchased preventives because of the 'desire ... to follow their social and pleasurable inclinations' (NSW 1904b: 30). A witness from the Salvation Army said middle-class couples 'desire not to have children in order to have more social pleasure' (NSW 1904b: 187). Some witnesses thought working-class people did not want large families because they wanted to go out dancing, to the theatre and on picnics. John West said: 
Among the working class, the object of lessening their births is very often the fear of poverty, and in others it is on account of curtailing their pleasures and enjoyments. (NSW 1904b: 199)

Edmund Riley, a plasterer and president of the Sydney Labour Council, argued that education had increased working-class people's aspirations:

If you want people to remain still in their social state you must not give them free education. When people's minds are educated they crave for enjoyments and pleasures ... The industrial classes ... have as much right to their enjoyment and pleasure as any other class. (NSW 1904b: 196)

Witness statements to the NSW royal commission outlined above clearly show a concern for the 'quality' of children rather than 'quantity'. Dr Grace Russell from the Sydney Women's Hospital considered that, ' $[w]$ ith a good many of the thinking women, it is a very strong reason for limitation-the anxiety for the well-being of those children that are born' (NSW 1904b: 110). Books and magazine articles of the time support the view that parents were concerned about the 'quality' of their children. The Dawn, a women's journal published monthly in Sydney between May 1888 and July 1905, contained many articles about bringing up children-for instance, 'Sleep' (November 1889), 'About babies' (February 1891) and 'Shall all children learn music' (March 1894) (Lawson 1990). This journal had subscribers across eastern Australia, including Tasmania. Parents focused not only on their children's health and education, but also on their behaviour. A history of manners in colonial Australia cites several magazine articles published in the late 1880s on the need to teach children good manners, and two books on etiquette published at the turn of the century included chapters on children's manners (Russell 2010). Ida McAulay's diaries indicate that theories about child development were in circulation in the late 1890s. On 20 January 1897, she wrote about her young son: 'I almost agree with J.P. Richter that the most important time for training in a child's life is the first year' (McAulay 1897).

We do not know whether the 'opportunity costs' for women of having children were a consideration in family limitation during the historical fertility decline in Tasmania, since there is no information as to whether married women with dependent children worked outside the home other than in the family business or farm. One of the witnesses to the 1903 royal commission, Annie Duncan, an inspector of factories and shops, reported the situation in Sydney, saying: 
I think the proportion of women with very young children is very small. I think the married women who are employed in factories are mostly women whose children are out of hand. (NSW 1904b: 130)

The evidence to support Caldwell's 'wealth flows' theory is not strong but is supportive. Although education became compulsory in Tasmania in 1868, average attendance at government schools was 70-75 per cent throughout the final quarter of the 19th century. Children who were absent regularly from government schools were those of the urban and rural working classes and of smaller farmers. These children helped in the home or on the family farm or were working in paid employment outside the family home to supplement the family income. These families would have been more likely to regard children as 'workers' than 'dependants'.

Most witnesses to the NSW royal commission discussed children in terms of their economic dependency on their parents, although some said the situation was different in the country. Dr Worrall, when asked why women in country districts had more children than those in the towns, replied:

It is because they are more useful in the country; the children are more useful on the farms ... they are equally poor but the children are really a source of wealth to them. (NSW 1904b: 92)

\section{Secularisation}

The history of religion in Tasmania and in Australia generally and the historical sources of the time support theories of secularisation and fertility decline. Religion did not have a major effect on people's lives in Australia and did not affect the adoption of ideas and values about fertility control and its practice.

Although many religious denominations became established in the early decades of the colony, Tasmania appears to have been a relatively secular society throughout the 19th and early 20th centuries. Tasmanians generally married in church, had their children baptised and were buried according to religious rites, but in most cases the church did not have a major influence over their lives. 
Amy Walker and Ida McAulay were the antithesis of one another regarding religious practices. Walker, the daughter of an Anglican clergyman, participated very actively in the life of St Mary's Gretna, attending every Sunday, playing the harmonium in church, teaching Sunday school and was a member of the church society (Walker 1880, 1881, 1882, 1898). McAulay, on the other hand, had no religious beliefs. In 1900 , she discussed evolution with her five-year-old son, gave him a lecture on agnosticism and told him that 'father and I do not believe in God' (McAulay 1900).

Historians generally agree that, in the early decades of the colony, most of the Tasmanian population did not have a strong religious affiliation (Breward 1988, 1993; Robson and Roe 1997; Boyce 2010; Reynolds 2012). Religion was generally not as important to people in Australia as it was in the United Kingdom or the United States (Breward 1988). By the 1850s and 1860s, religious groups in Australia did not have a strong influence on people's political and social attitudes and values. Anglicans, like other religious groups, reflected the political and social realities of its community rather than shaping the community' (Breward 1993: 45).

During the 1880s, there were calls for social reform in several areas of Australian life, such as widening the grounds for divorce (Breward 1993). This resulted in a further weakening of the control of religious groups and indicated that 'secular considerations were, by the 1880s, receiving more weight than historic theological ones' (Breward 1993: 83). The testimonies of clergymen of all the main religious denominations to the 1903 NSW Royal Commission show the church was very much opposed to the use of birth control (NSW 1904b), but this had little effect on its practice.

Many witnesses to the commission testified that a weakening of 'religious feeling' was one of the main factors responsible for the adoption of preventives and the subsequent decline in the birth rate (NSW 1904a: 17). Cardinal Patrick Moran, the Catholic Archbishop of Sydney, thought:

In relation to my own religious people, there has been a marvelous [sic] development of respect for religion and devotion to all exercises of religion ... But speaking of the community in general ... there is a great decay of religious sentiment and what I would call manifest indifference to religion on the part of a great number of the citizens of New South Wales. (NSW 1904b: 210) 
Dr Cosby William Morgan, a general practitioner who had worked in both the country and the city, thought:

The decay of the religious sense in the people ... has conduced to the causes which bring about the decline in the birth rate. I think that their moral sense is blunted and that they do not care very much about religion at all. (NSW 1904b: 26)

Similarly, police sergeant Sawtell attributed the fall in the birth rate to the bad home training of children; both education and religious ... On Sundays you will see our young people in the parks and down the harbour engaged in all kinds of outdoor amusements, instead of being at Sunday school or attending religious instruction of some sort. (NSW 1904b: 136)

\section{Dr Scot-Skirving said:}

The whole of this community, from the highest to the lowest are prone to use preventives. They are simply ordinary worldly people in whom religious sentiment has no very active measure of importance in their daily life and thought. (NSW 1904b: 100)

Even people who had religious views and were regular churchgoers often made their own decisions about what they believed was right rather than taking the church's views. John West told the commissioners he did not think

religious sentiment has much effect ... I know persons who are very strong attendants at their church who are equally as bad as those who do not go ... My knowledge of the world is that the pocket plays the more important part than religious sentiment with most people in the community. (NSW 1904b: 199-200)

A witness from the Salvation Army testified that ' $[s]$ ome people who profess to have strong religious views still carry on these practices' (NSW 1904b: 187), while the Reverend Howell-Price said: 'They only admit the religious sense in as far as it may touch them in other directions-absolutely not in this' (NSW 1904b: 215). 
While the clergymen appearing before the commission were very much opposed to fertility control, several thought it too sensitive a subject to bring up in the pulpit. Dr William Mckay, a Presbyterian minister, said:

There is a natural shrinking from treating of such subjects; and although we clergymen know that such things have been going on yet, either out of a fear of bringing subjects before the young people that should not be brought before them or out of natural delicacy, the matter has been tabooed and not treated from the pulpit. (NSW 1904b: 204)

Other clergymen were afraid to preach against fertility control publicly because they thought they would alienate some of their parishioners, which would reduce their stipend. Dr Howell-Price said:

I have spoken to the clergy about it and they have given me the answer back that they are afraid to speak of it from the pulpit ... lest they should give offence and thus cause the offenders to withdraw their contributions from the churches. (NSW 1904b: 215-16)

The Reverend Howell-Price reported that when he preached against birth control from the pulpit, 'I know it injured myself for awhile' (NSW 1904b: 217). The Reverend Patrick Stephen, a Methodist clergyman, added:

I have scarcely preached to my congregation upon that subject. I touched upon it in a general way ... It is a most difficult thing to handle a delicate subject in public ... Sometimes when a clergyman preaches to his congregation on this subject he is called to account by some members of his church ... and in consequence of that and of circumstance that he may incur the ill will of his parishioners, he refrains from alluding to it at all. (NSW 1904b: 276)

Dr Howell-Price reported that clergymen who preached against prevention had been ridiculed publicly:

Canon Potter, of Melbourne was the first, I think in Australia to introduce the matter into the pulpit and he was lampooned afterwards in one of the illustrated papers in Victoria. (NSW 1904b: 215) 


\section{Changes in women's roles and status}

Historical sources of the time show women played a major role in the historical fertility decline in all the Australian colonies, due to changes in their roles in the family and in society that were occurring at this time. A recent article examining women's roles as agents in fertility decisionmaking concludes they were central agents in Australia's historical fertility transition (McDonald and Moyle 2018) — an argument also made by Cook (2000) and Anderson and Mackinnon (2015).

The fertility decline in Australia took place during a period in which ideas about women's rights began to spread throughout the colonies (Quiggin 1988; Anderson 1999). Books and pamphlets about women's rights began to circulate from the 1860s. This was followed by various feminist campaigns in the 1880 s and 1890 s on matters relating to property and child custody reform, public health and universal suffrage (Anderson 1999).

Several laws were enacted in Australia in the late 19th and early 20th centuries relating to women's rights.

Divorce was first made legal in all colonies except New South Wales between 1858 and 1864, with Tasmania enacting divorce laws in 1860 (Finlay 2001). New South Wales enacted a similar divorce law in 1873. Adultery was the only ground for divorce in the first divorce acts, but there was a double standard in that a husband could divorce his wife for adultery, but a wife could only divorce her husband for adultery under limited circumstances. New South Wales, although late to enact the first divorce laws, amended its Act in 1881 to treat husband and wife equally regarding adultery. Desertion, drunkenness and imprisonment were introduced as grounds for divorce in Victoria in 1889 and in New South Wales in 1892, but not until 1919 in Tasmania. The 1919 Tasmanian Act also abolished the double standard relating to adultery.

The Married Women's Property Act, which gave women the right to own and control property, was passed in 1884 in Victoria, in New South Wales in 1889 and in the other colonies in the early 1890s, including Tasmania, in 1893 (Cowie 2009). 
Australia was one of the first of the English-speaking and European countries to give women the vote. South Australia and Western Australia gave women the right to vote shortly before Federation in 1901 and the other four colonies shortly after.

The feminist reform movement in Australia in the second half of the 19th century was to a large extent the province of elite and middle-class women (Quiggin 1988; Anderson 1999). Feminist writings were read mainly by these women, and the reformers involved in the various campaigns were also middle-class. However, feminist ideas gradually spread throughout the other strata of society. The introduction of compulsory primary education in the colonies from the late 1860s improved both men's and women's literacy, their access to information and their openness to new ideas. Women also began to participate in higher education in the late 1890 s and early 1900s (McAulay 1898, 1899, 1904). From the late 1890 s, women began to participate in many other areas of society that had formerly been closed to them. For instance, in Tasmania, women rode bicycles and participated in sporting teams, with some of these teams for women only.

Feminist organisations did not openly support the use of artificial means of birth control. However, some individual feminists advocated the use of contraception and a few, such as Brettena Smyth in Melbourne, sold contraceptives (Quiggin 1988; Bongiorno 2012; McDonald and Moyle 2018). Feminists were divided in their views about contraception, with some opposing birth control because they thought it would encourage excessive male sexuality (Bongiorno 2012). The efforts of the feminists, however, led to a society in which all women were increasingly being acknowledged as individuals with rights, and this began to change the concepts of marriage, the family and relations between the sexes (Anderson 1999). Feminism started to change women's position in the domestic sphere and husbands became more concerned about their wives' situation regarding childbearing (Quiggin 1988). Upper-class women were the first to achieve rights within the domestic sphere, as is evident from the diaries of Amy Walker and Ida McAulay.

In the late 19th century, Tasmanian upper-class women ran their own households and led independent lives outside the home. Walker and McAulay chose all the furnishings for their homes and hired and managed the servants (McAulay 1899; Walker 1879). Both women also travelled without their husbands. Amy Walker often travelled on her own or with her small daughter to visit her parents and siblings in Hobart (Walker 1879), 
while Ida McAulay often travelled on her own within Tasmania and to other colonies (McAulay 1897, 1898, 1899). Both women had extensive social lives. Walker $(1879,1880)$ went to cricket matches, the theatre, the opera, concerts and balls and 'at homes' at Government House, while McAulay $(1897,1899,1903)$ went to the theatre, attended lectures and took part in debating and reading groups. Ida McAulay had her own private income, which she controlled herself. On 30 June 1897, she wrote: 'Got my first quarterly dividend from the Mt Lyell mine'; and, on 26 May 1900, she bought ' 33 shares in the Sawpit Gully Gold and Silver Mining Company at 6/- per share' (McAulay 1897, 1900).

Both Amy and Ida were interested in issues outside the home. Amy's diaries refer to the capture of the Kelly Gang bushrangers in 1880, the taking of the Tasmanian census in 1881 and the polling for Federation in 1898 (Walker 1880, 1881, 1898). Ida's diaries for 1899 have comments on the progress of the Dreyfus trial in France and, from October, on the war in Transvaal (McAulay 1899). Amy showed a keen interest in her husband's farming of the estate and took over its management when he died in 1906. Ida was a declared feminist, was active in women's clubs and discussion groups and was president of the Tasmanian Women's Suffrage Association (later the Tasmanian Women's Political Organisation) from 1903 to 1905 .

The 1903 NSW Royal Commission on the Decline of the Birth-Rate was evidence of resistance to the changes that were occurring in women's lives (NSW 1904a, 1904b). For women, there was nothing more fundamental than having control over their fertility. The commission was overwhelmingly male. All 13 commissioners were well-established professional men and, of the 92 witnesses who were not commissioners, only nine were women. Feminists boycotted the commission. A noted feminist, Rose Scott, refused her invitation to appear before the commission and gave speeches to women's organisations attacking the commissioners for conducting this type of inquiry into women's affairs (Allen 1990).

The commission concluded that women had played a crucial role in the 19th-century fertility decline in New South Wales. They viewed women's 'selfishness' in adopting birth control practices as primarily responsible for the fall of the birth rate in that colony since the 1880s (NSW 1904a: 17). Despite the commissioners' vehement opposition to prevention and to the changes in women's behaviour, attitudes and lives, the commission made very few recommendations to remedy 'the various evils which are indicated by the evidence as the causes of the decline in the birth- 
rate' (NSW 1904a: 2). While they recommended changes to the sale of abortifacients and to the registration of lying-in homes to prevent them being used by abortionists, it appears they felt powerless to stop the sale and/or use of preventives and to halt or reverse the changes that had and were occurring in women's lives.

Witness statements to the royal commission show women had a very active role in determining the size of their families.

Evidence outlined above shows that many of the artificial contraceptives used were female-controlled and the sale of female-controlled preventives had overtaken the sale of male-controlled preventives in the late 19th and early 20th centuries. A study of birth control practices in Australia from the 1930s until the 1960s similarly found that the use of femalecontrolled methods of contraception was considerably higher than the use of the male-controlled methods of withdrawal and the condom (Cook 2000). The study also found the use of female-controlled methods was markedly higher in Australia than in England over the same period.

Methods of prevention such as withdrawal required husbands to cooperate with their wives, while female-controlled preventives could be used without a husband's knowledge. Witnesses to the royal commission indicated that some husbands and wives agreed about the use of prevention, whereas others did not. Dr Worrall reported that there was an 'inclination of both husband and wife to limit their families. They generally discuss the matter and make up their minds' (NSW 1904b: 89). Similarly, Witness E, talking about the use of prevention, thought: 'The women are not always the ones to blame, in fact it is sometimes made a sort of agreement on marrying' (NSW 1904b: 189). John West, however, said of the working classes:

My experience has taught me that there is a great deal of difference between the two parties and very often the husband is opposed to the wife doing this sort of thing and it has caused disagreements. (NSW 1904b: 199)

Abortion was clearly a female-controlled method of limiting family size and one that some women employed without their husband's knowledge and/or consent (Allen 1990).

Many witnesses to the royal commission reported that women were proactive in purchasing preventives and in seeking out ways to procure an abortion. Pharmacists in Sydney said both men and women came into their shops to purchase preventives or to ask for abortifacients. 
William Park, the Pitt Street pharmacist, said 'all classes of people, gentlemen, ladies, wives of working men' came in to buy these goods (NSW 1904b: 40). George Stevens, the pharmacist in a working-class district of Sydney, reported: 'Married women come in and ask for them over the counter ... Sometimes they ask me for means to procure abortion' (NSW 1904b: 44). As noted above, one of the Sydney city pharmacies had set up a special kiosk staffed by a 'nurse' where women could buy 'female' goods, including preventives.

Several witnesses expressed dismay at the ease with which women publicly spoke about family limitation. Dr Watson-Munro, a surgeon at two large Sydney hospitals, said: 'Many classes of women are pretty free in expressing the desire to evade the pregnant condition' (NSW 1904b: 48). Dr Scot-Skirving reported that he was

sometimes a little surprised at the casual way in which a woman, practically a stranger, will talk to me of the most inner sexual relations with as much sangfroid as if she were talking about having lunch. (NSW 1904b: 98)

As outlined above, women were an important source of information for other women on the ideas and values about family limitation and knowledge about methods of prevention.

One reason put forward by witnesses for the reluctance of women to have large families was their concern about the pain and risks of childbirth. Dr Scot-Skirving thought: 'There are a good number of women who have a weak shrinkage from the pains of maternity and they hate the disagreeables of gestation' (NSW 1904b: 98). Some doctors, however, thought these fears were not justified. Dr Watson-Munro said:

They may talk about the trouble of the act of parturition or the pain of it, but I do not think that that is a very dreadful thing any more now than at any other time in the history of the world.

(NSW 1904b: 80)

At the same time, however, the commissioners expressed grave concerns about 'unduly numerous' deaths of women in childbirth and the effects of childbirth on women's health and subsequent fertility (NSW 1904a: 31). Two witnesses to the commission, pharmacist Edward Fuss and newsagent John Hume, spoke about the ill effects of continual childbearing on women's health, while the Reverend William Rutledge, a Methodist minister, commented: 'Some women have been worn out, almost done to death, by over-bearing of children' (NSW 1904b: 226). 
Women's concerns about the risks of childbirth were clearly realistic. 'In 19th century Tasmania, causes of death connected with maternity were the second most common, after tuberculosis, for women of childbearing age' (Kippen 2002c: 173). Using the World Health Organization (WHO) definition of maternal death (WHO 1992, cited in Kippen 2002c), the maternal mortality rate ranged from 3.4 to 7.9 deaths per 1,000 live births over the period 1860-99 (Kippen 2002c: 180). There was a large increase in maternal mortality in the early 1870 s, a decline from the late 1870 s to the late 1880 s and then an increase in the 1890s. The maternal death rate ranged from 0.6 to 1.2 deaths per 1,000 population between 1860 and 1899 and followed the trend in the maternal mortality rate until the 1890s, when it began to fall in relation to the maternal mortality rate. This is undoubtedly due to the fall in fertility during this period. Kippen (2002c: 188-90) also found many 'hidden maternal deaths' in the period 1880-99, with more than one-third of maternal deaths not registered as such. Given these rates, it is highly likely most women in Tasmania of childbearing age would have been acquainted with or have heard of someone who had died in childbirth.

A letter to a newspaper cited in the royal commission's report (NSW 1904b: 282) suggested couples were limiting their fertility because of their concerns about the husband's survival. A male breadwinner's death would leave his wife with the sole responsibility of supporting her dependent children and in many circumstances facing poverty. These concerns were realistic given that, in the four marriage cohorts in this study, the number of husbands who died during their wife's childbearing years was around the same as the number of wives (Appendix A: Table A.16).

Several witnesses to the commission considered one of the main reasons women did not want many children was because of their love of 'pleasure'. Women of all classes wanted a life outside the domestic sphere and did not want to be burdened with a large family. Witness $E$ thought: 'The practice of preventing conception is followed because of the desire of women to have social pleasures' (NSW 1904b: 180); while Dr Creed, a Sydney general practitioner, and Dr Harris, a Newcastle general practitioner, both said women did not want to be 'bothered with children' (NSW 1904b: 124, 138). The Reverend Howell-Price thought the reason women wanted to limit the size of their family was: 
[T] he children tied them too much to the home and they did not wish to become slaves ... they want to be free, free from home ties and home duties as far as possible ... they desire to have more leisure, apparently for the pursuit of their own pleasure. (NSW 1904b: 214-15)

Although he did not express it in this way, the Reverend Howell-Price thought women's aversion to having a large family was due to the influence of feminism:

This desire to prevent the birth of children can undoubtedly be taken as a particular instance of a general relaxation of control over women, which has become the general sentiment during the last 30 or 40 years ... That relaxation of all control has led them into this particular desire to be free from restriction in that way too. (NSW 1904b: 216)

Women of all classes were expressing feminist sentiments at the turn of the 20th century and standing up for what they perceived as their rights.

Ida McAulay, in her diary, talked about how a working-class woman had confronted her, an upper-class woman, to stand up for her daughter's rights. On 14 November 1899, Ida McAulay wrote that the mother of one of her servants had objected to Ida's treatment of her daughter: 'I got a most impertinent card from Alice's mother saying she would not allow her to come back as this was the second time she had come home ill' (McAulay 1899). On 17 November 1899, Ida wrote that when Alice and her mother came to get Alice's box, 'strong words were exchanged and she was violent and abusive' (McAulay 1899).

The Hobart Mercury on 31 December 1900 reported an argument between Emma Dixon and her husband, John (1870 cohort), in which Emma asserted her rights in relation to her husband:

John Dixon, milkman, residing at the retreat farm, Lower Sandy Bay, deposed that ... his wife, left home at 6.20 in a cart to accompany him on his rounds. When about 100 yards from the farm she said she was going to have a new set of harness for the horse they were driving. He replied that they must pay a certain account first. She then said she had earned the money as well as he, that she was going to do as she liked and she would not go with him. 
Emma subsequently jumped down from the cart, was run over by the wheels and died later that day. The death was ruled 'accidental' by the coroner.

\section{Conclusion}

Overall, the historical sources quoted in this chapter provide support for most theories of why marital fertility declined in the late 19th and early 20th centuries. In the conclusion to this book, I summarise how the quantitative findings from Chapters 6 and 7 and the qualitative findings from this chapter answer the questions of when, how and why fertility declined in Tasmania at this time. I also examine how these findings compare with those from studies of the fertility decline in other English-speaking countries and in Western Europe, discussed in Chapter 1, and from other studies of the historical fertility decline in Australia, discussed in Chapter 2. 
This text is taken from Australia's Fertility Transition: A study of 19th-century Tasmania, by Helen Moyle, published 2020 by ANU Press, The Australian National University, Canberra, Australia.

doi.org/10.22459/AFT.2020.08 